\title{
16. LIGHT HYDROCARBONS IN SEDIMENTS OF THE SULU SEA BASIN (SITE 768): GENETIC CHARACTERIZATION BY MOLECULAR AND STABLE ISOTOPE COMPOSITION ${ }^{1}$
}

\author{
Ulrich Berner ${ }^{2}$ and Philippe Bertrand ${ }^{3}$
}

\begin{abstract}
Geochemical investigations on gases and interstitial waters from ODP Site 768 (Sulu Trench/Philippines) demonstrate the application of molecular gas composition in combination with stable isotope analyses to the genetic classification of light hydrocarbons. ${ }^{13} \mathrm{C} /{ }^{12} \mathrm{C}$ and $\mathrm{D} / \mathrm{H}$ ratios of methane from gas pockets in cores and gases desorbed from frozen sediments by a vacuum/acid treatment suggest a microbial generation of methane by a $\mathrm{CO}_{2}$ reducing process in sediments with low sulfate concentrations. Isotope data and molecular composition of sediment gases liberated by the vacuum/acid treatment seem to be affected by a secondary desorption process during sampling. A comparison between the $\mathrm{D} / \mathrm{H}$ ratios of methane from gas pockets and interstitial $\mathrm{H}_{2} \mathrm{O}$ points to an in-situ generation of methane down to a sub-bottom depth of approx. $720 \mathrm{~m}$. Below this depth hydrogen isotope data indicate a migration of light hydrocarbons into pyroclastic sediments at this site. The occurrence of higher hydrocarbons (propane to pentane) in gases from gas pockets coincides with the vertical distribution of mature organic matter. Gases within the zone of mature organic matter are gases of a mixed microbial and thermal origin.
\end{abstract}

\section{INTRODUCTION}

During ODP Leg 124, where an objective was to determine the ages of the Celebes and Sulu Seas, a total of five sites was drilled in Philippine waters. Organic geochemical investigations on board the ODP drill ship were carried out with the purpose of safety monitoring (Rangin, Silver, von Breymann, et al., 1990). Shore-based studies on gases from Site 768 demonstrate the genetic characterization of light hydrocarbons by analyses of molecular compositions of gases in combination with stable isotope ratios. These investigations continue the work by Whiticar et al. (1986) and authors cited therein.

\section{METHODS}

Gases from visual gas pockets of the sediment cores of Site 768 were expanded into vacutainers on board JOIDES Resolution before cutting the liners. In addition, gases of selected frozen $\left(a t-20^{\circ} \mathrm{C}\right.$ ) sediments from Site 768 were desorbed in the Bundesanstalt für Geowissenschaften und Rohstoffe (BGR) laboratory by a vacuum/acid treatment described by Faber and Stahl (1983). This vacuum/acid procedure liberates a combination of free and adsorbed gases from the sediments. These gases are referred to as "total" gases. A total of 46 gas samples was analyzed for their molecular composition, their carbon, and depending on the amount, for their hydrogen isotope ratios at the BGR laboratory.

The molecular composition of hydrocarbon gases was determined by standard Flame Ionization Detector (FID) analyses utilizing a Siemens Sichromat 2 gas chromatograph provided with a capillary pre-column $(50 \mathrm{~m})$ and a $\mathrm{Al}_{2} \mathrm{O}_{3}$-filled capillary main-column $(50 \mathrm{~m})$. Nitrogen was used as a carrier gas at a flow rate of $2.93 \mathrm{~mL} / \mathrm{min}$. The chromatographic separation was carried out isothermally at $90^{\circ} \mathrm{C}$

For the isotope analyses the individual gas components were separated chromatographically and subsequently combusted to $\mathrm{CO}_{2}$ and $\mathrm{H}_{2} \mathrm{O}$ using a preparation line described by

\footnotetext{
1 Silver, E. A., Rangin, C., von Breymann, M. T., et al., 1991. Proc. ODP, Sci. Results, 124: College Station, TX (Ocean Drilling Program).

${ }^{2}$ Bundesanstalt für Geowissenschaften and Rohstoffe, Stillweg 2, D-3000 Hannover 51, Federal Republic of Germany.

${ }^{3}$ URPO, URA 724, University of Orleans, 45067 Orleans Cedex 2, France.
}

Dumke et al. (1989). The combustion product $\mathrm{H}_{2} \mathrm{O}$ is reduced to $\mathrm{H}_{2} \mathrm{O}$ by reaction with zinc in sealed glass tubes at $450^{\circ} \mathrm{C}$. Interstitial fluids of Site 768 were collected using pressure filtration of the sediments (see Rangin, Silver, von Breymann, et al., 1990). The $\mathrm{D} / \mathrm{H}$ ratio of the interstitial water was determined on $\mathrm{H}_{2}$ generated following the in-vitro reduction of $\mathrm{H}_{2} \mathrm{O}$ on zinc (Dumke et al., 1989).

The stable isotope measurements on $\mathrm{CO}_{2}$ from combustion of hydrocarbons were carried out using a Finnigan MAT 250 mass spectrometer. For the D/H analyses a Finnigan Delta mass spectrometer was used. Isotope ratios are reported in the usual $\delta$-notation relative to the PDB (Pee Dee Belemnite) standard for carbon and SMOW (Standard Mean Ocean Water) standard for hydrogen:

$$
d R=\left[\left[\left(R_{\mathrm{a}} / R_{\mathrm{b}}\right)_{\text {sample }} /\left(R_{\mathrm{a}} / R_{\mathrm{b}}\right)_{\text {standard }}\right]-1\right] \cdot 1000
$$

where $R_{\mathrm{a}} / R_{\mathrm{b}}$ is ${ }^{13} \mathrm{C} /{ }^{12} \mathrm{C}$ and $\mathrm{D} / \mathrm{H}$, respectively.

\section{RESULTS AND DISCUSSION}

\section{Analyses on Gas Pockets}

The hydrogen and carbon isotope ratios of methane from gas pockets of Site 768 collected below the sulfate reduction zone (Rangin, Silver, von Breymann et al., 1990) indicate a bacterial methane generation (Fig. 1, Table 1) through $\mathrm{CO}_{2}$ reduction (Whiticar et al., 1986). The bacterial origin of methane is also confirmed by the combination of gas ratios of methane over the sum of ethane and propane and carbon isotope data of methane (Fig. 2, Table 1). Methane is the dominant component in all gas pockets, but hydrocarbons ethane to pentane are observed also.

The isotope profile of methane at Site 768 shows a steady decrease of the ${ }^{13} \mathrm{C}$ isotope with depth (Fig. 3, Table 1). This trend with depth is opposite to that which would result from the fractionation depletion model of Claypool and Kaplan (1974). In this model there is an increase of the ${ }^{13} \mathrm{C}$ isotope in bacterial methane with increasing depth, due to a depletion of the ${ }^{12} \mathrm{C}$ isotope in the substrate $\mathrm{CO}_{2}$ that is preferentially consumed by bacteria during methanogenesis. The vertical variation of carbon isotope ratios of methane at Site 768 there- 


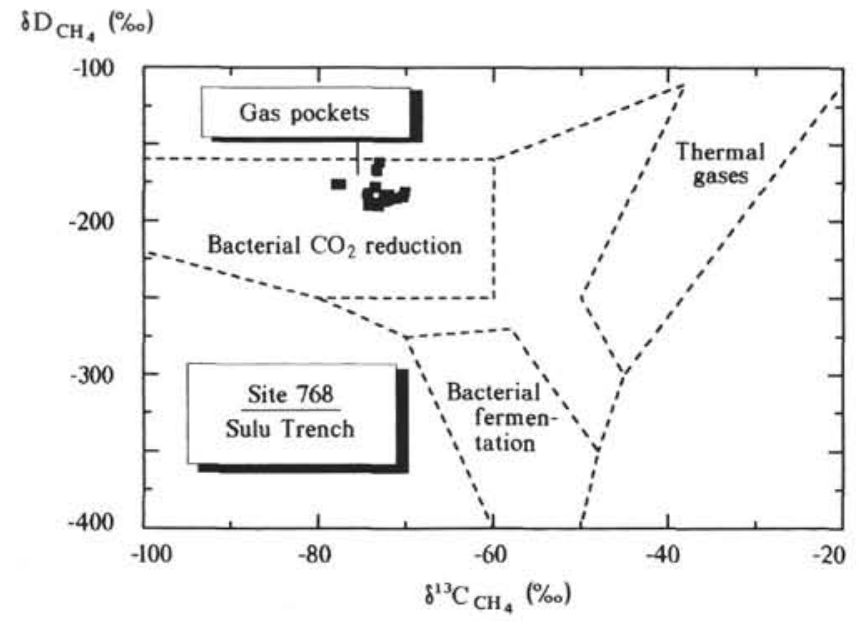

Figure 1. Hydrogen and carbon isotope ratios of methanes from gas pockets indicate a bacterial methane generation through $\mathrm{CO}_{2}$ reduction (diagram modified after Whiticar et al., 1986).

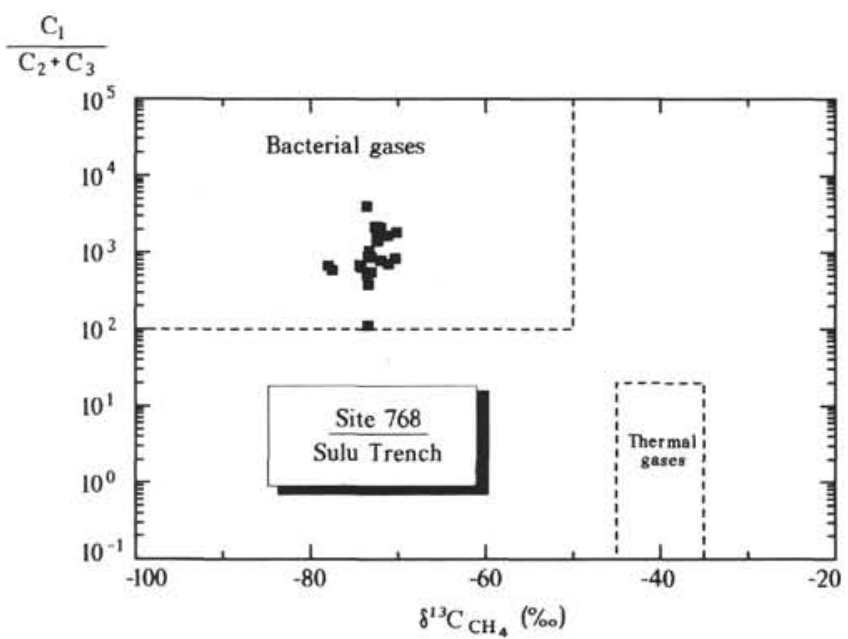

Figure 2. Carbon isotope ratios of methane and molecular ratios indicate a bacterial origin of methane from gas pockets (diagram modified after Bernard, 1979).

fore cannot be explained by such a model. We either have to assume that if the methane isotope values reflect the primary isotope ratios of the substrate $\mathrm{CO}_{2}$, which would be the case if the methane was generated in situ, this substrate has been affected by a mechanism other than ${ }^{12} \mathrm{C}$ depletion through bacterial activity or that the methane was not generated "in place." As there is not sufficient data on the dissolved $\mathrm{CO}_{2}$ of pore waters in this depth range, because only small quantities of water could be obtained, we cannot solve the problem by comparing methane and $\mathrm{CO}_{2}$ carbon isotope data.

In addition to a bacterial generation of methane, thermogenic hydrocarbon generation is detected at a sub-bottom depth greater than $450 \mathrm{~m}$ (Table 1) where, according to Bertrand et al. (this volume), the maturity of the organic matter reaches more than $0.5 \%$ vitrinite reflectance. The occurrence of higher hydrocarbons coincides with the zone of mature organic matter. We conclude from the molecular composition of gases from the thermogenic zone that these gases are mixed gases of microbial and thermal origins. Although methane is the dominant compo-

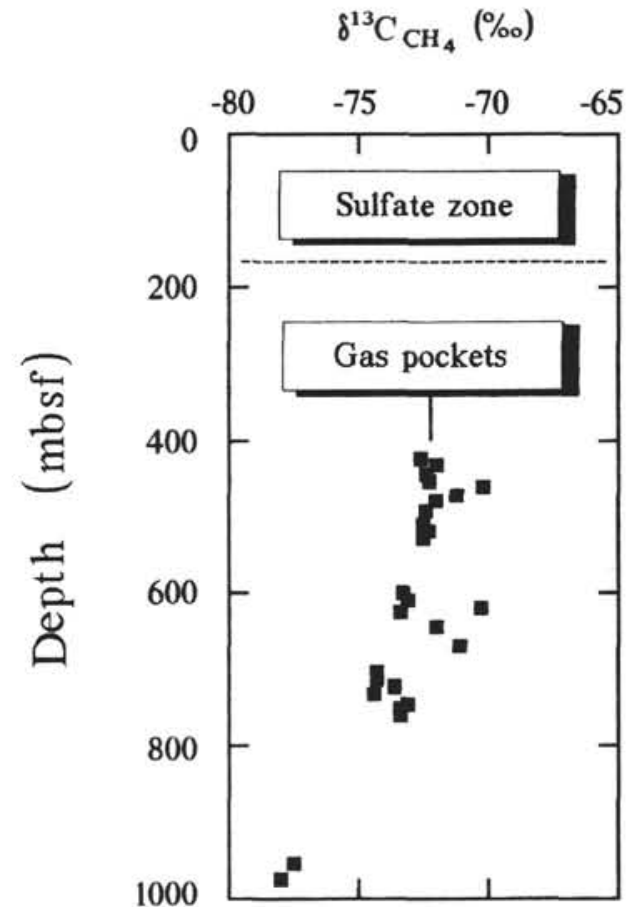

Figure 3. Isotope profile of methane from gas pockets at Site 768 shows a steady decrease of the ${ }^{13} \mathrm{C}$ isotope with depth.

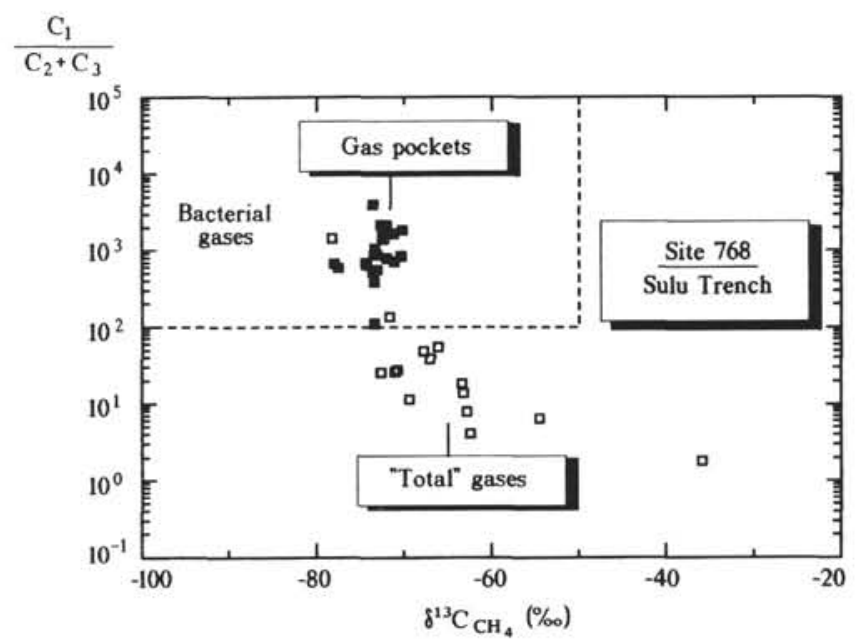

Figure 4. Carbon isotope ratios of methane and molecular ratios indicate a correlated decrease of the light isotope with decreasing methane concentrations in "total" gases.

nent in gas pockets, significant amounts of ethane to pentanes were also detected (Table 1).

\section{Analyses on "Total" Gases}

The hydrogen and carbon isotope ratios of methane of total gases released from sediments of Site 768 by the vacuum/acid treatment indicate a bacterial origin (Table 2) through $\mathrm{CO}_{2}$ reduction (Whiticar et al., 1986). Obviously, the datum points deviate from those of the gas pockets to more positive carbon values, indicating a depletion of the light isotope ${ }^{12} \mathrm{C}$ (Fig. 4). The ratio of methane to the sum of ethane and propane in combination with the carbon isotope data of methane (Fig. 4, Table 2) shows that the methane of the desorbed gases is different from 
Table 1. Molecular composition and isotope data of methane from gas pockets of Site 768.

\begin{tabular}{|c|c|c|c|c|c|c|c|c|c|c|c|}
\hline $\begin{array}{c}\text { Sample } \\
124-768 \mathrm{C} \text { - }\end{array}$ & $\begin{array}{l}\text { Depth } \\
\text { (mbsf) }\end{array}$ & $\begin{array}{c}\mathrm{CH}_{4} \\
(\%)\end{array}$ & $\begin{array}{l}\mathrm{C}_{2} \mathrm{H}_{6} \\
(\mathrm{ppm})\end{array}$ & $\begin{array}{l}\mathrm{C}_{3} \mathrm{H}_{8} \\
(\mathrm{ppm})\end{array}$ & $\begin{array}{l}\mathrm{i}-\mathrm{C}_{4} \\
(\mathrm{ppm})\end{array}$ & $\begin{array}{c}\mathrm{n}-\mathrm{C}_{4} \\
(\mathrm{ppm})\end{array}$ & $\begin{array}{c}\mathrm{i}-\mathrm{C}_{5} \\
(\mathrm{ppm})\end{array}$ & $\begin{array}{c}\mathrm{n}-\mathrm{C}_{5} \\
(\mathrm{ppm})\end{array}$ & $\frac{C_{1}}{C_{2}+C_{3}}$ & $\begin{array}{l}\delta^{13} \mathrm{C} \\
\mathrm{CH}_{4} \\
(\% \circ)\end{array}$ & $\begin{array}{c}8 \mathrm{D} \\
\mathrm{CH}_{4} \\
(\%)\end{array}$ \\
\hline $8 R 2-145$ & 423.65 & 99.95 & 464 & 3 & 1 & 0 & 8 & 0 & 2140 & -72.6 & - \\
\hline $9 R 2-43$ & 432.13 & 99.95 & 474 & 3 & 3 & 0 & 0 & 1 & 2095 & -72.0 & -184 \\
\hline $10 R 3-51$ & 443.41 & 99.95 & 459 & 2 & 2 & 0 & 0 & 0 & 2168 & -72.4 & -183 \\
\hline $11 R 3-67$ & 453.27 & 99.95 & 475 & 3 & 0 & 0 & 0 & 0 & 2091 & -72.3 & -183 \\
\hline $12 \mathrm{R} 1-124$ & 460.44 & 99.94 & 540 & 6 & 6 & 0 & 0 & 0 & 1830 & -70.2 & -181 \\
\hline $13 R 2-103$ & 471.43 & 99.94 & 604 & 5 & 6 & 0 & 0 & 0 & 1641 & -71.2 & -185 \\
\hline $14 \mathrm{R} 1-60$ & 479.10 & 99.94 & 569 & 25 & 9 & 0 & 0 & 0 & 1682 & -72.0 & -183 \\
\hline $15 R 3-59$ & 491.79 & 99.94 & 580 & 5 & 3 & 0 & 0 & 0 & 1708 & -72.4 & -187 \\
\hline 17R2-71 & 509.71 & 99.94 & 556 & 12 & 5 & 0 & 0 & 0 & 1760 & -72.5 & -185 \\
\hline 18R2-38 & 519.08 & 99.93 & 684 & 19 & 9 & 0 & 0 & 0 & 1421 & -72.3 & -184 \\
\hline 19R1-135 & 528.25 & 99.93 & 703 & 17 & 9 & 0 & 0 & 0 & 1388 & -72.5 & -187 \\
\hline $19 R 2-20$ & 528.60 & 99.93 & 637 & 16 & 7 & 0 & 0 & 0 & 1530 & -72.5 & -185 \\
\hline 26R4-32 & 599.42 & 99.90 & 886 & 65 & 26 & 0 & 0 & 0 & 1050 & -73.3 & -190 \\
\hline 27R4-2 & 608.82 & 99.88 & 1060 & 82 & 33 & 1 & 4 & 0 & 875 & -73.1 & -190 \\
\hline $28 \mathrm{R} 5-56$ & 620.46 & 99.88 & 1097 & 96 & 34 & 2 & 7 & 0 & 837 & -70.3 & -184 \\
\hline $29 R 2-21$ & 625.21 & 99.88 & 1066 & 89 & 30 & 0 & 8 & 1 & 865 & -73.4 & -189 \\
\hline $31 \mathrm{R} 1-88$ & 643.68 & 99.87 & 1179 & 96 & 30 & 2 & 4 & 0 & 783 & -72.0 & -186 \\
\hline 33R6-27 & 669.87 & 99.85 & 1310 & 110 & 30 & 2 & 6 & 0 & 703 & -71.1 & -185 \\
\hline $37 R 2-112$ & 703.42 & 99.84 & 1430 & 116 & 35 & 0 & 10 & 0 & 646 & -74.3 & -190 \\
\hline $38 R 2-90$ & 712.90 & 99.84 & 1426 & 37 & 9 & 3 & 9 & 0 & 682 & -74.3 & -188 \\
\hline $39 \mathrm{R} 1-80$ & 721.00 & 99.59 & 1600 & 300 & 0 & 14 & 0 & 0 & 524 & -73.6 & -178 \\
\hline $39 R 3-112$ & 724.32 & 99.97 & 248 & 0 & 2 & 0 & 0 & 0 & 4031 & -73.6 & -188 \\
\hline $40 \mathrm{R} 2-56$ & 731.96 & 99.85 & 1360 & 100 & 30 & 0 & 0 & 0 & 684 & -74.4 & -182 \\
\hline $41 R 5-6$ & 745.66 & 99.79 & 1800 & 0 & 300 & 0 & 10 & 0 & 554 & -73.1 & -162 \\
\hline $42 R 2-100$ & 751.80 & 99.61 & 2200 & 400 & 300 & 0 & 0 & 0 & 383 & -73.4 & -167 \\
\hline $43 R 2-23$ & 760.23 & 99.10 & 8900 & 0 & 100 & 0 & 0 & 0 & 111 & -73.4 & - \\
\hline $63 R 3-52$ & 953.82 & 99.83 & 1700 & 0 & 0 & 0 & 0 & 0 & 587 & -77.5 & -176 \\
\hline $65 R 4-5$ & 974.25 & 99.84 & 1500 & 0 & 100 & 0 & 0 & 0 & 666 & -78.0 & -176 \\
\hline
\end{tabular}

Note: $\mathrm{ppb}=\left(\mathrm{g}_{\text {gas }} / \mathrm{g}_{\text {wet sediment }}\right) \times 10^{9}$

the methane of the gas pockets. The observed depletion of the light carbon isotope in the methane of the desorbed gases with decreasing methane concentration points to a secondary alteration of the methane. This observation can be attributed either to bacterial oxidation or to a degassing fractionation of methane as both processes result in a loss of the light isotope (Faber and Stahl, 1984; Whiticar and Faber, 1986). The time between collection of the sediment sample from the core and freezing of the sediment is too short ( 5 to $10 \mathrm{~min}$.) to allow oxidizing bacteria to consume significant quantities of methane in the presence of oxygen, but within this time interval it is likely that a significant quantity of methane is lost by desorption from the sediment and diffusion into the air. This process can lead to an increase of the heavy ${ }^{13} \mathrm{C}$ and $\mathrm{D}$ isotopes in the gas fraction remaining in the sediment because of the lower desorption capacity of molecules containing heavy isotopes.

Because of the possible secondary alteration of total sediment gases they are excluded from the further discussion.

\section{Comparison of Hydrogen Isotope Data of Pore Waters and Methane of Gas Pockets}

No dissolved $\mathrm{CO}_{2}$ could be obtained from pore waters of the hydrocarbon- bearing sediments of Site 768 . For the differentiation of autochthonous and allochthonous bacterial methane, a comparison between the hydrogen isotope ratios of the substrate water and the methane is essential. The hydrogen isotopic composition of autochthonous biogenic methane is related to the isotopic composition of the substrate $\mathrm{H}_{2} \mathrm{O}$ on which the bacteria live (Whiticar et al., 1986), whereas the isotope ratios of allochthonous gases are expected to show no relationship to the isotopic compositions of the water. For the purpose of comparing hydrogen isotope ratios of interstitial waters and methane (because samples of water and methane are not from the same depth) we first have to describe the change of the $\mathrm{D} / \mathrm{H}$ ratio of water with increasing depth for Site 768 . The $\mathrm{D} / \mathrm{H}$ ratios of interstitial waters decrease with increasing depth from $+6 \%$ to
$-6 \%$ over a depth range of $600 \mathrm{~m}$ (Fig. 5A, Table 3). Similar findings have been reported from other DSDP/ODP sites (Lawrence, 1989 and literature cited therein). The most likely explanation for this observation is a diffusion of isotopically light water from the basaltic basement rather than an isotopic shift due to mineral alteration or temperature-induced isotope differentiation through diffusion (Lawrence, 1989). The observed vertical isotope variation can be approximated by the linear regression function

$$
\text { Depth }=-53.91 \delta \mathrm{D}_{\mathrm{H}_{2} \mathrm{O}}+264.95 \text {. }
$$

From the hydrogen isotope fractionation function of water and methane for methane formation from $\mathrm{CO}_{2}$ reduction (Whiticar et al., 1986)

$$
\mathrm{dDCH}_{4}=\delta \mathrm{D}_{\mathrm{H}_{2} \mathrm{O}}-180 \pm 10,
$$

it is possible to predict the hydrogen isotopic variation with depth for an in-situ generation of methane at Site 768 by rearranging (3) and substituting into (2). This calculated depth trend for the hydrogen isotopic variation of methane (extrapolated to a depth of $800 \mathrm{~m}$ ) is shown in Figure 5B and compared to the measured hydrogen isotope ratios of methanes from gas pockets of Site 768 (Table 1). Obviously, the measured data follow the predicted isotope trend between 400 and $700 \mathrm{~m}$.

Gases from deeper $700 \mathrm{~m}$ deviate from the calculated trend toward more positive isotope ratios. The observed coincidence of calculated and measured isotope values of methane between 400 and $700 \mathrm{~m}$ indicates that bacterial methane at this depth interval was generated in situ. Gases that deviate from the calculated isotope trend in the lowermost part of the sediment section toward positive values are likely to be allochthonous. These gases are found in turbidites and pyro- 
Table 2. Molecular composition and isotope data of total gases in Holes $768 \mathrm{~B}$ and 768C.

\begin{tabular}{|c|c|c|c|c|c|c|c|c|c|}
\hline $\begin{array}{c}\text { Sample } \\
124-\end{array}$ & $\begin{array}{l}\text { Depth } \\
\text { (mbsf) }\end{array}$ & $\begin{array}{l}\mathrm{CH}_{4} \\
(\mathrm{ppb})\end{array}$ & $\begin{array}{l}\mathrm{C}_{2} \mathrm{H}_{6} \\
(\mathrm{ppb})\end{array}$ & $\begin{array}{l}\mathrm{C}_{3} \mathrm{H}_{8} \\
(\mathrm{ppb})\end{array}$ & $\begin{array}{l}\mathrm{i}-\mathrm{C}_{4} \\
(\mathrm{ppb})\end{array}$ & $\begin{array}{l}\mathrm{n}-\mathrm{C}_{4} \\
(\mathrm{ppb})\end{array}$ & $\frac{C_{1}}{C_{2}+C_{3}}$ & $\begin{array}{l}\delta^{13} \mathrm{C} \\
\mathrm{CH}_{4} \\
(\%)\end{array}$ & $\begin{array}{l}\delta \mathrm{D} \\
\mathrm{CH}_{4} \\
(\%)\end{array}$ \\
\hline 768B-3H-CC, $2 \mathrm{I}-23$ & 23.46 & 6.61 & 3.59 & 2.16 & 0.00 & 0.00 & 2.44 & - & - \\
\hline $768 \mathrm{~B}-5 \mathrm{H}-\mathrm{CC}, 11-13$ & 42.18 & 15.45 & 10.68 & 6.42 & 0.00 & 0.00 & 1.92 & - & - \\
\hline 768B-9H-СC, 27-29 & 80.52 & 18.10 & 13.02 & 8.57 & 0.00 & 0.00 & 1.79 & -35.9 & - \\
\hline $768 \mathrm{~B}-13 \mathrm{H}-\mathrm{CC}, 29-31$ & 118.53 & 49.80 & 36.69 & 22.78 & 0.00 & 0.00 & 1.78 & - & - \\
\hline 768B-19H-CC, $41-43$ & 173.82 & 10.68 & 4.48 & 10.65 & 0.00 & 0.00 & 1.70 & - & - \\
\hline $768 \mathrm{~B}-22 \mathrm{H}-\mathrm{CC}, 38-40$ & 200.99 & 25.15 & 1.95 & 0.80 & 0.00 & 0.00 & 18.90 & - & - \\
\hline 768B-28X-CC, $37-39$ & 247.00 & 9.21 & 0.78 & 0.00 & 0.00 & 0.00 & 22.04 & - & - \\
\hline 768B-34X-CC, $35-37$ & 300.26 & 200.05 & 2.35 & 0.59 & 0.00 & 0.00 & 135.83 & -71.7 & - \\
\hline $768 \mathrm{C}-1 \mathrm{R}-\mathrm{CC}, 14-16$ & 359.86 & 76.83 & 9.12 & 13.48 & 14.91 & 17.27 & 7.86 & -62.8 & - \\
\hline $768 \mathrm{C}-7 \mathrm{R}-\mathrm{CC}, 14-16$ & 419.19 & 507.75 & 16.32 & 1.64 & 1.22 & 0.68 & 54.50 & -66.1 & - \\
\hline $768 \mathrm{C}-13 \mathrm{R}-\mathrm{CC}, 18-20$ & 474.26 & 46.51 & 1.50 & 0.44 & 0.44 & 0.23 & 48.55 & -67.8 & - \\
\hline 768C-19R-CC, 15-17 & 529.85 & 250.86 & 14.42 & 3.46 & 6.63 & 0.59 & 28.01 & -70.7 & - \\
\hline 768C-22R-CC, $15-17$ & 559.30 & 58.48 & 3.86 & 3.00 & 3.60 & 1.02 & 18.55 & -63.4 & - \\
\hline 768C-22R-CC, 13-15 & 623.17 & 714.46 & 27.34 & 10.36 & 8.70 & 1.15 & 39.01 & -67.0 & -165 \\
\hline 768C-34R-CC, 16-18 & 681.07 & 395.19 & 42.19 & 33.06 & 29.83 & 5.32 & 11.44 & -69.4 & - \\
\hline 768C-37R-CC, $12-14$ & 709.15 & 45.97 & 11.96 & 13.29 & 12.45 & 3.35 & 4.10 & -62.4 & - \\
\hline 768C-43R-CC, $13-15$ & 762.32 & 52.32 & 2.31 & 2.07 & 1.68 & 0.77 & 26.28 & -71.0 & - \\
\hline $768 \mathrm{C}-48 \mathrm{R}-\mathrm{CC}, 0-2$ & 813.91 & 10.43 & 2.48 & 0.86 & 0.00 & 0.00 & 6.38 & -54.5 & - \\
\hline $768 \mathrm{C}-54 \mathrm{R}-\mathrm{CC}, 44-46$ & 871.00 & 30.48 & 2.00 & 0.30 & 0.00 & 0.00 & 25.88 & -72.6 & - \\
\hline 768C-60R-CC, $13-15$ & 931.31 & 110.75 & 1.81 & 0.39 & 0.00 & 0.00 & 100.00 & - & - \\
\hline 768C-65R-CC, $33-35$ & 977.12 & 752.22 & 0.85 & 0.30 & 0.00 & 0.00 & 1427.42 & -78.19 & -159 \\
\hline $768 \mathrm{C}-72 \mathrm{R} 2,66-68$ & 1039.06 & 104.86 & 10.69 & 5.23 & 0.00 & 0.00 & 13.79 & -63.19 & - \\
\hline
\end{tabular}

Table 3. Hydrogen isotope data from pore waters in Holes $768 \mathrm{~B}$ and $768 \mathrm{C}$.

\begin{tabular}{|c|c|c|}
\hline $\begin{array}{c}\text { Sample } \\
124-\end{array}$ & $\begin{array}{l}\text { Depth } \\
\text { (mbsf) }\end{array}$ & $\begin{array}{r}\delta \mathrm{D} \\
\mathrm{H}_{2} \mathrm{O} \\
(\%)\end{array}$ \\
\hline $768 \mathrm{~B}-1 \mathrm{H}-2,145-150$ & 2.95 & 1.9 \\
\hline $768 \mathrm{~B}-2 \mathrm{H}-5,145-150$ & 11.45 & 3.0 \\
\hline $768 \mathrm{~B}-3 \mathrm{H}-5,145-150$ & 20.95 & 4.9 \\
\hline $768 \mathrm{~B}-4 \mathrm{H}-5,145-150$ & 30.45 & 5.5 \\
\hline $768 \mathrm{~B}-5 \mathrm{H}-4,145-150$ & 38.45 & 6.0 \\
\hline $768 \mathrm{~B}-6 \mathrm{H}-5,145-150$ & 49.45 & 4.0 \\
\hline $768 \mathrm{~B}-7 \mathrm{H}-5,145-150$ & 58.95 & 4.1 \\
\hline $768 \mathrm{~B}-8 \mathrm{H}-5,145-150$ & 68.45 & 4.4 \\
\hline $768 \mathrm{~B}-9 \mathrm{H}-5,145-150$ & 77.95 & 4.2 \\
\hline $768 \mathrm{~B}-10 \mathrm{H}-5,145-150$ & 87.45 & 3.7 \\
\hline $768 \mathrm{~B}-13 \mathrm{H}-5,145-150$ & 115.95 & 3.1 \\
\hline $768 \mathrm{~B}-16 \mathrm{H}-5,145-150$ & 144.45 & 2.5 \\
\hline $768 \mathrm{~B}-19 \mathrm{H}-5,140-150$ & 172.90 & -0.5 \\
\hline $768 \mathrm{~B}-22 \mathrm{H}-4,140-150$ & 198.70 & -0.5 \\
\hline $768 \mathrm{~B}-26 \mathrm{X}-2,140-150$ & 222.20 & -0.5 \\
\hline $768 \mathrm{~B}-28 \mathrm{X}-4,140-150$ & 244.50 & -0.4 \\
\hline $768 \mathrm{~B}-31 \mathrm{X}-5,140-150$ & 274.90 & -1.8 \\
\hline $768 \mathrm{~B}-34 \mathrm{X}-2,140-150$ & 299.30 & -1.7 \\
\hline $768 \mathrm{~B}-37 \mathrm{X}-2,140-150$ & 328.40 & 0.1 \\
\hline $768 \mathrm{C}-1 \mathrm{R}-3,140-150$ & 357.60 & -0.2 \\
\hline $768 \mathrm{C}-4 \mathrm{R}-1,140-150$ & 383.50 & -2.6 \\
\hline $768 \mathrm{C}-7 \mathrm{R}-3,140-150$ & 415.50 & -4.4 \\
\hline $768 \mathrm{C}-10 \mathrm{R}-3,140-150$ & 444.30 & -3.5 \\
\hline $768 \mathrm{C}-13 \mathrm{R}-3,140-150$ & 473.30 & -3.6 \\
\hline $768 \mathrm{C}-16 \mathrm{R}-1,140-150$ & 499.30 & -3.3 \\
\hline $768 \mathrm{C}-19 \mathrm{R}-1,140-150$ & 528.30 & -2.8 \\
\hline $768 \mathrm{C}-22 \mathrm{R}-2,140-150$ & 558.70 & -2.7 \\
\hline $768 \mathrm{C}-26 \mathrm{R}-4,140-150$ & 600.50 & -5.3 \\
\hline $768 \mathrm{C}-28 \mathrm{R}-4,140-150$ & 619.80 & -3.1 \\
\hline
\end{tabular}

clastics with TOC values below $0.1 \%$ (Rangin, Silver, von Breymann et al., 1990).

These findings coincide with results from shipboard analyses of headspace gases concentrations (Rangin, Silver, von Breymann et al., 1990). Below $700 \mathrm{~m}$, gas concentrations in sediments that are lean in organic matter are, on average, one order of magnitude higher than gas concentrations in sediments with TOC values between $0.2 \%$ and $3.85 \%$ (Rangin, Silver, von Breymann et al., 1990). This observation clearly indicates that gases of the lowermost sediment section at Site 768 were not generated in situ.

The observed hydrogen isotope shift in gases of the lower section toward positive isotope values cannot be attributed to an admixture of thermal methane with higher deuterium concentration. Theoretically, this result would be possible, as organic matter at Site 768 has the appropriate maturity to generate thermal hydrocarbons (see below). In this case, however, the carbon isotope values also should increase but do not. A comparison of Figures 3 and 5B shows that the two isotope species show diverse trends. The high $\mathrm{D} / \mathrm{H}$ ratios of the allochthonous gases, which are similar and/or more positive than values from gases from the initial zone of methanogenesis of Site 768 , indicate that these gases were generated from pore waters with low $\mathrm{D} / \mathrm{H}$ ratios similar to those of the upper part of the bacterial methane zone. But generally, a direct extrapolation of the generation depth from hydrogen isotope values of the methane is not possible because the vertical distribution of $\mathrm{D} / \mathrm{H}$ ratios of the pore waters in the sediment column of the Sulu Trench may vary locally.

The gases were most likely transported by advective flows from higher structures of the Sulu Trench Basin into deeper structures, possibly via permeable turbidites and/or pyroclastics that are present in this basin. The allochthonous gases detected at Site 768 were likely generated in the Sulu Trench Basin itself and not on the near Cagayan Ridge because the two sites drilled on the Cagayan Ridge (Site 769 and Site 771), which terminated in basaltic rocks, showed background methane concentrations in sediments associated with high amounts of sulfate in pore waters (Rangin, Silver, von Breymann et al., 1990).

\section{CONCLUSIONS}

1. Carbon and hydrogen isotope ratios of methane in sediments at Site 768 point to methane formation through microbial reduction of $\mathrm{CO}_{2}$.

2. A comparison between calculated $\mathrm{D} / \mathrm{H}$ ratios of methane deduced from the isotope ratios of interstitial $\mathrm{H}_{2} \mathrm{O}$ and measured deuterium concentration of methane points to an in-situ generation of methane down to a sub-bottom depth of approximately $700 \mathrm{~m}$.

3. Below $700 \mathrm{mbsf}$, hydrogen isotope data indicate a migration of light hydrocarbons into pyroclastic sediments. 


\section{ACKNOWLEDGMENTS}

The work of U. Berner was financially supported by the Deutsche Forschungsgemeinschaft through grant Fa 175/3-1. The work of Ph. Bertrand was financially supported by the Centre National de la Recherche Scientifique (CNRS).

\section{REFERENCES}

Bernard, B. B., 1979. Light hydrocarbons in marine sediments [Ph.D. dissert.]. Texas A\&M Univ., College Station, Texas.

Claypool, G. E., and Kaplan, I. R., 1974. The origin and distribution of methane in marine sediments. In Kaplan, I. R. (Ed.), Natural Gases in Marine Sediments: New York (Plenum), 99-140.

Dumke, I., Faber, E., and Poggenburg, J., 1989. Determination of stable carbon and hydrogen isotopes of light hydrocarbons. Anal. Chem., 61:2149-2154.

Faber, E., and Stahl, J. W., 1983. Analytical procedure and results of an isotope geochemical surface survey in an area of the British North Sea. In Brooks, J. (Ed.), Petroleum Geochemistry and Exploration of Europe. Geol. Soc. Spec. Publ. London, 11:51-63. 1984. Geochemical surface exploration for hydrocarbons in the North Sea. AAPG Bull., 68:363-386.
Lawrence, J. R., 1989. The stable isotope geochemistry of deep-sea pore water. In Fritz, P., and Fontes, J. Ch. (Eds.), Handbook of Environmental Isotope Geo-chemistry (Vol. 3): New York (Elsevier), 317-356.

Rangin, C., Silver, E. A., von Breymann, M. T., et al., 1990. Proc. ODP, Init. Repts., 124: College Station, TX (Ocean Drilling Program).

Whiticar, M. J., and Faber, E., 1986. Methane oxidation in marine and limnic sediments and water columns. In Leythaeuser, D., and Rullkotter, J. (Eds.), Advances in Organic Geochemistry 1985: New York (Springer-Verlag), 759-768.

Whiticar, M. J., Faber, E., and Schoell, M., 1986. Biogenic methane formation in marine and freshwater environments: $\mathrm{CO}_{2}$ reduction vs. acetate fermentation-isotope evidence. Geochim. Cosmochim. Acta, 50:693-709.

Date of initial receipt: 28 June 1990 Date of Acceptance: 1 February 1991 Ms 124B-157

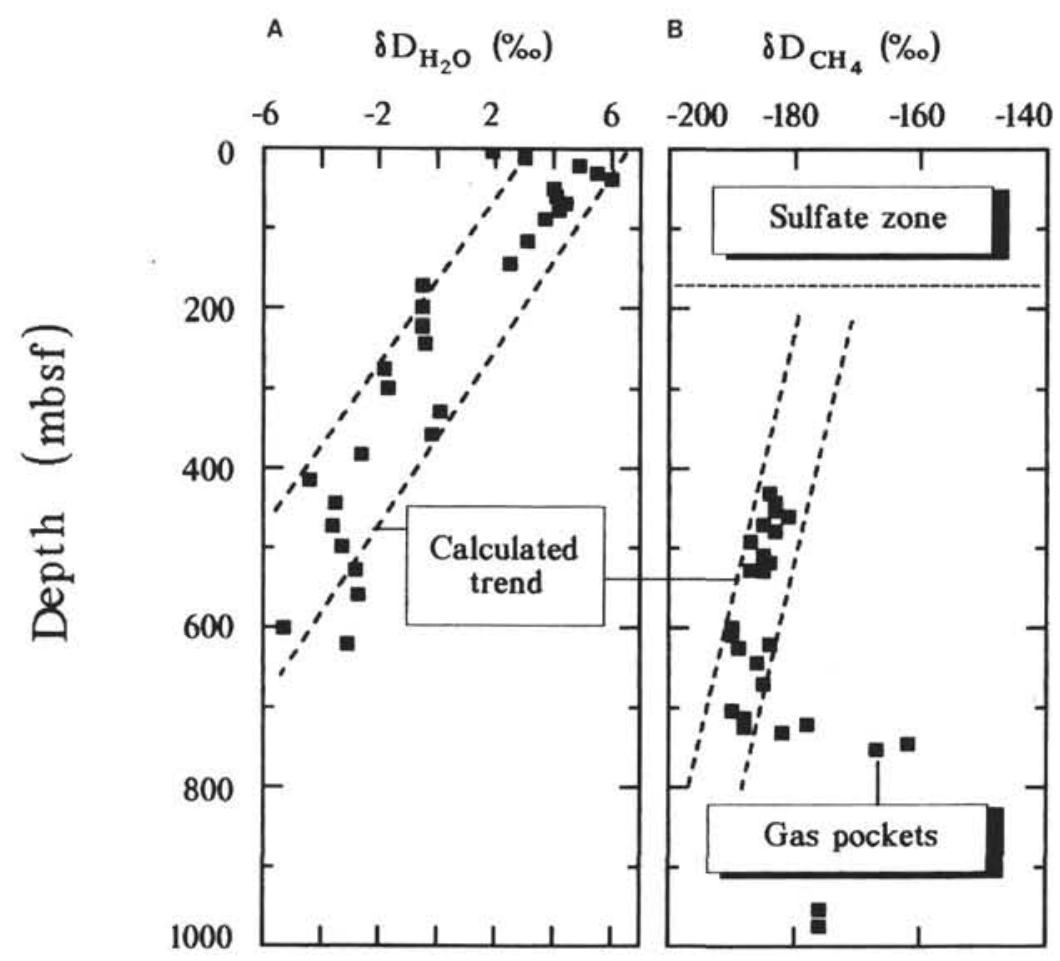

Figure 5. The D/H ratios of interstitial waters (A) decrease with increasing depth from $+6 \%$ to $-6 \%$ over a depth range of $600 \mathrm{~m}$. A calculated depth trend (B) for the hydrogen isotopic variation of methane deduced from the $\mathrm{D} / \mathrm{H}$ ratios of pore waters is compared to the measured hydrogen isotope ratios of methane from gas pockets at Site 768 . 